\title{
SARA HEINÄMAA
}

\section{USKOMINEN JA LUOTTAMUS}

\author{
KAKSI TULKINTAA MAAILMAVARMUUDEN LUONTEESTA
}

Jokapäiväisessä elämässä toimimme sen varmuuden varassa, että kaikki esineet, toiset ihmiset ja oma ruumiimme ovat läsnä ja paikallaan maailmassa muiden asioiden keskellä. ${ }^{1}$ Ja vaikka esineet eivät juuri nyt olisi käsillä, niin uskomme niiden olevan saatavilla - joko helposti tai hankalammin, välittömästi tai eri välinein. Ja silloinkin, kun oliot katoavat tavanomaisilta paikoiltaan, kun ne menetetään tai kun ne tuhoutuvat, niin uskomme, että ne (tai ainakin niiden osatekijät) jatkavat olemistaan jossakin muualla kaikenkattavassa aika-avaruudessa.

Erilaisissa mielen häiriötiloissa tämä jokapäiväinen varmuus asioiden käsilläolosta ja saavutettavuudesta alkaa horjua. Esimerkiksi masentuneena omat askeleet, jotka normaalisti iskeytyvät empimättä kadun kivetykseen, etenevät kuin hapuillen tai tunnustellen. Katu ei enää jäsenny pettämättömänä pintana, joka kannattelee kiireisiä askeleitani, vaan saattaa hetkittäin tuntua tahmealta ja raskaalta kuin sula asvaltti tai ilmetä kutsuvana alustana johon voisin jäädä lepäämään. Ei niin, että kadun aistimelliset piirteet muuttuisivat - asvaltti pysyy mustana ja kivetys kiiltävänä - mutta nämä piirteet alkavat jäsentyä uudelleen ja muodostavat kokonaisuuden, joka liikuttaa kehoani kummallisella, normaalista poikkeavalla tavalla.

Syvässä masennuksessa ympäristö saattaa kokonaan menettää affektiiviset merkityksensä eli ne piirteensä, jotka normaalisti liikuttavat meitä. Kadun pinta ei enää ilmene sen enempää kannattelevana kuin kutsuvana vaan on kokonaan lakannut suuntaamasta kävelijää. Syvästi masentuneet potilaat kuvaavat tätä tilaa "tunnottomuuden tunteeksi" ja kertovat sen ulottuvan esineistä ja esineympäristöstä kaikkein läheisimpiin ihmissuhteisiin ja jopa omaan ruumiiseen. Saksalainen fenomenologi ja psykiatri Thomas Fuchs kuvaa masentuneen "tunnottomuutta" seuraavasti:

Potilas ei enää aisti omaa kehoaan; maku, haju, jopa lämmön ja kivun tunteet ovat kadonneet, kaikki näyttäytyy elottomana. Ihmiset ja esineet näyttäytyvät tyhjinä ja epätodellisina, maailma on tyhjä tai lakannut olemasta. Potilas saattaa ajatella kuolleensa ja odottavansa hautaamista; hän saattaa kieltää oman olemisensa ja maailman olemassaolon. Eräs potilaani koki, että hänen kehonsa, vatsansa ja suolensa olivat näivettyneet niin, että jäljellä oli vain tyhjä kuori. Koko ruumis, hän väitti, oli kuivunut, mikään ei enää 
liikkunut. Hän oli vakuuttunut siitä, että kaikki hänen sukulaisensa olivat menehtyneet ja että hän oli yksinään maailmassa ja pakotettu elämään tässä kuolleessa ruumiissa. $^{2}$

Skitsofreniassa maailmanjäsennys muuttuu toisenlaisella tavalla; kyseenalaiseksi tulee ennen muuta oman ja vieraan välinen normaali ero. Tällainen kyseenalaistus saattaa alkaa jo kauan ennen varsinaista psykoottista tilaa. Eräs noin 30-vuotias potilas kertoi esimerkiksi, että jo 16-vuotiaana hän menetti varmuutensa siitä, mitkä asiat kuuluivat hänelle ja mitkä eivät. ${ }^{3}$ Kyse ei tässä ole mistään tavanomaisesta epäselvyydestä, vaan epävarmuus ulottuu myös niihin esineisiin ja asioihin, jotka tavallisesti kykenemme nimeämään omiksemme ilman minkäänlaisia vaikeuksia, suoraan ilman pohdintaa ja päättelyä.

Ensin tämä potilas menetti varmuutensa siitä, mitkä esineet kuuluivat hänelle. Kirjakaupassa hän epäili myyjän salaa vaihtaneen hänen juuri ostamansa kirjat toisiin. Potilas ei elänyt epäilystään pelkästään sisäisenä tuntemuksena tai ajatuksena vaan myös toimintaa motivoivana epävarmuutena: hän ei ainoastaan ajatellut kirjojen vaihtuneen vaan päätyi antamaan epäilyksenalaiset kirjat pois ostaakseen tilalle uusia. Epäily eteni esineistä vaatteisiin ja kaikkein läheisimpiin ja tutuimpiin tarvikkeisiin. Hoitava lääkäri kuvaa näitä vaikeuksia seuraavasti:

Pukeutuminen vei häneltä loputtomasti aikaa, sillä hänen täytyi koskettaa vaatteita useita kertoja ja toistaa liikkeensä yhä uudelleen varmistuakseen, että vaatteet olivat hänen omansa. Hän ei tiennyt, pitelikö hän housuja käsissään oikein päin ja missä järjestyksessä pukeutuminen piti suorittaa. ${ }^{4}$

21-vuotiaana potilas alkoi menettää varmuuttaan myös siitä, että kädet, joilla hän toimi ja suoritti erilaisia käytännöllisiä tehtäviä, todella kuuluivat hänelle itselleen. Hänen täytyi jatkuvasti tarkkailla käsiään ja varmistaa, että ne kytkeytyivät käsivar- sien kautta muuhun ruumiiseen, ja hänen täytyi yhä uudelleen kääntää päätään varmistuakseen siitä, ettei joku toinen liikuttanut käsiä hänen takanaan. "Jokainen tehtävä oli kuin aritmeettinen ongelma, jota täytyi harkita äärimmäisen keskittyneesti. Niinpä hän juuttui arkisiin toimiin ja tuli yhä epätoivoisemmaksi." 5

Artikkelini tarkoituksena on valaista sen erityislaatuisen varmuuden rakennetta, jolla kohtaamme maailman ja todellisuuden normaalissa arkipäiväisessä elämässämme. Nimitän tätä varmuutta seuraavassa yksinkertaisuuden vuoksi "maailmavarmuudeksi”. Kuten olemme nähneet tämä varmuus saattaa horjua, ja myös horjuminen - sen mahdollisuus - kertoo meille jotakin varmuuden luonteesta ja rakentumisesta. Kyse ei ole yksittäisestä vakaumuksesta vaan normaalin tietoisuuden ja kokemuksen kehyksestä, joka jatkuvasti kannattelee ja jäsentää arkitoimintaamme ja tekojamme, yhä lailla teoreettisia kuin käytännöllisiä. ${ }^{6}$

Etenen selvittämällä lyhyesti, miten kaksi 1900-luvun johtavaa fenomenologia ovat kuvanneet ja jäsentäneet maailmavarmuutta. Artikkelini pääajatuksena on, että maailmavarmuus voidaan käsittää kahdella eri tavalla: ensinnäkin uskomukselle ja tiedolle tyypillisenä valikoivana sitoumuksena mutta toisaalta myös kokonaisvaltaisena luottamuksena. Tutkin näitä mahdollisuuksia selvittämällä ensin saksalaisen Edmund Husserlin näkemystä maailmavarmuudesta ja sitoumuksesta maailman läsnäoloon. Keskityn sitten ranskalaisen Maurice Merleau-Pontyn malliin, jossa maailmavarmuus muistuttaa olemassaoloa koskevan uskomuksen sijasta affektiivista luottamusta. Tarkoituksenani ei ole paneutua Husserlin ja Merleau-Pontyn filosofioiden monimutkaisiin, systemaattisiin ja vaikutushistoriallisiin suhteisiin, vaan esitän ainoastaan muutaman perusidean lähtökohdaksi yksityiskohtaisemmille tutkimuksille. ${ }^{7}$

Tätä ennen on kuitenkin tarpeen painottaa muutamaa ratkaisevaa seikkaa. Vaikka fenomenologia käsittelee inhimillistä 
kokemusta ja sen eri muotoja - uskomuksesta ja tietämisestä tunteisiin ja mielialoihin - se ei suinkaan ole minkäänlaista psykologiaa vaan on filosofinen hanke. Päämääränä on kuvata ja analysoida kokemuksen kaikkein yleisimpiä, välttämättömiä rakennepiirteitä ja näiden piirteiden keskinäisiä suhteita.

Havainnon kohdalla, esimerkiksi, kyse ei ole siitä, että tutkittaisiin ihmisten havaintojen moninaisia sisältöjä. Sen sijaan että selvitettäisiin, mitä tai miten ihmiset näkevät tai miten nisäkkäät havaitsevat, pyritään löytämään kaiken mahdollisen havainnon välttämättömät rakennetekijät ja kuvaamaan nämä tekijät sellaisella käsitteistöllä, joka ei nojaa mihinkään yksittäisiin havaintokokemuksiin eikä sellaisten joukkoon. Näin ollen kuvauksen tulee kattaa yhtä lailla inhimilliset havaitsijat kuin eläimetkin, yhtä lailla oman kulttuurimme havaintokokemukset kuin vieraiden kulttuurien, yhtä lailla nykyiset havainnon muodot kuin menneet ja kadonneet. $^{8}$

Lisäksi on painotettava, että fenomenologit eivät suinkaan kuvaa maailmavarmuuden luonnetta terapeuttisista syistä, auttaakseen niitä, jotka kärsivät varmuuden horjumisesta - vaikka fenomenologien työllä näyttääkin olevan tällaisia suotuisia seuraamuksia. Fenomenologit keskittävät huomionsa perustavaan maailmasuhteeseen sen vuoksi, että se on perusta kaikelle kokemiselle, yhtä lailla affektiiviselle ja emotionaaliselle kuin tiedolliselle ja älylliselle. Kaikki empiirinen tutkimus nojaa maailmavarmuuteen ja varmuuteen maailmallisten olioiden käsilläolosta. Fenomenologinen kysymys kuuluu, minkälaista on tämä perustava varmuus ja minkälaisena se antaa meille maailmamme.

\section{VAKAUMUS MAAILMAN \\ OLEMASSAOLOSTA}

Edmund Husserl lähti kehittämään fenomenologiaansa ymmärtääkseen tieteellisten hankkeiden kokonaisuutta. Jotta tie- teellinen toiminta olisi mielekästä, täytyy tieteellisiksi nimettyjä väitteitä, teorioita ja menetelmiä yhdistää jokin tekijä. Tämä tekijä oli Husserlin mukaan perustelemisen ja evidenssin etsimisen toiminnoissa.?

Husserlin mielenkiinto oli siis alussa keskittynyt tieteelliseen ajatteluun ja tämän vuoksi erityisesti tiedolliset aktit, uskomukset ja väitteet olivat hänen filosofisten tutkimustensa keskiössä. Tiedollinen painos vaikutti myös Husserlin varhaiseen näkemykseen maailmavarmuuden luonteesta; hän käsitti sen esi-kognitiiviseksi tilaksi. ${ }^{10}$

Husserlin ensimmäisten muotoilujen mukaan maailmaan kohdistuva varmuus on luonteeltaan uskomuksen kaltainen tila, eräänlainen perususkomus. Se merkitsee sitoumusta siihen, että maailma olioiden kokonaisuutena on olemassa ja tavoitettavissa eri osiltaan. Yksittäiset olemassaoloa koskevat oletukset ja väitteet nojaavat tähän luonnolliseen perusasenteeseen. Maailmavarmuus alustaa yhtä lailla arkisia uskomuksiamme kuin tieteellisiä väittämiämme. ${ }^{11}$

Tämä ei toki tarkoita, että päivittäisissä toimissamme jatkuvasti miettisimme ja ajattelisimme maailman kokonaisuutta ja toistaisimme mielessämme uskomustamme sen todellisuuteen, vaan ainoastaan sitä, että kaikki toimemme nojaavat implisiittiseen, ääneenlausumattomaan vakaumukseen maailman olemassaolosta ja pysyvyydestä.

On painotettava, että Husserlin maailmakäsitys on laaja ja kattava. Hän ei monien aikalaistensa tavoin rajaa maailmaa fysiikan universumiksi vaan näkee maailman koostuvan monista erilaisista olioista, voimista, tapahtumista ja asiantiloista. Alkeishiukkasten ja fysikaalisten voimien (sähkö-, magneetti- ja gravitaatiovoimien) lisäksi maailmaan kuuluvat kaikki luonnonoliot eli eläimet, kasvit ja muut mahdolliset eliöt sekä näiden elinympäristöt (muun muassa vuoret, joet, meret ja metsät). Myös kaikki kulttuuriesineet ovat maailman osia. Teoreettisten olioiden 
ja luonnonolioiden lisäksi löydämme siis maailmasta esineet, välineet, instituutiot, lait, kielet ja taideteokset. Ja toki myös ihmiset erilaisine yhteisöineen kuuluvat tähän maailmaan.

Husserl näkee todellisuuden kerroksellisena, mutta hänen käsityksensä maailman kerrosten järjestyksestä poikkeaa merkittävällä tavalla nykyisestä standardikäsityksestä. Kokemusmaailman perusta ei ole objektiivisten tieteiden keksimissä tai osoittamissa teoreettisissa olioissa; maailma ei koostu esimerkiksi alkeishiukkasista, vaan päinvastoin alkeishiukkaset ovat monimutkaisen abstrahoivan ajattelun tulosta. Maailman perusta on sen sijaan aistihavainnon antamissa olioissa, ja maailmavarmuus on varmuutta havaintomaailman läsnä- ja käsilläolemisesta. ${ }^{12}$

Fyysikko voi toki kuvata maailman alkeishiukkasten kokonaisuudeksi mutta fenomenologin mukaan ainoastaan siksi ja siltä perustalta, että hän elää arkimaailman todellisuudessa, joka antaa mielensä, voimansa ja suuntansa hänen abstrahoivalle lähestymistavalleen. Fysikaalisen maailman olemismielen perustana on toisin sanoen käytännöllinen arkimaailma, joka edelleen rakentuu havainnon aistimellisen todellisuuden varaan. ${ }^{13}$

Niinpä myös kokemus aika-avaruudesta on kerrostunutta. Fysiikan yhtenäisen ja äärettömän aika-avaruuden perustana on havaintomaailman hyvin eri tavalla jäsentynyt tilallisuus. Havaittu tila avautuu eri suuntiin elävän ruumiin muodostamasta nollapisteestä: havaintokohteet ovat havaitsevan kehon yläpuolella tai alapuolella, oikealla tai vasemmalla, edessä tai takana. Jokainen keho on tällaisen tilallisen suuntautumisen nollakohta, ja kaikkien elävien olentojen yhteinen tila on näiden nollapisteiden muodostama dynaaminen järjestelmä.

Tärkeää on vielä huomata yksi Husserlin varhaisajattelun piirre. Husserl esittää Ideenteoksen ensimmäisessä niteessä, että havaintokohde on kokemuksen perustavalla tasolla puhdas kaikista affektiivisista ja käytännöllisistä piirteistä. Hän ei tarkoita, että arkikokemuksemme olisi vailla arvoja ja päämääriä, päinvastoin arkimaailman oliot ilmenevät meille yleensä arvokkaina ja tavoiteltavina, tai arvottomina ja vältettävinä, ja me reagoimme tai vastaamme niiden erilaisiin piirteisiin. Husserl ainoastaan esittää, että tällaiset kokemuksen kohteet ovat rakentuneet primitiivisemmistä kohteista, jotka ilmenevät pelkästään värien, muotojen ja muiden aistipiirteiden kokonaisuuksina. ${ }^{14}$ Masentuneen ihmisen kokemus osoittaisi tämän analyysin mukaan, että vaikka affektiivisuus ei muodosta omaa erillistä kokemuskerrostaan, niin kokemus voi kuitenkin menettää affektiivisuutensa - jollei kokonaan niin ainakin hyvin suurelta osin - niin että jäljelle jää paljaita aistimellisia piirteitä ja niiden käsitteellisiä jäsennyksiä. ${ }^{15}$

\section{LUOTTAMUS JA USKO MAAILMAAN}

Merleau-Ponty tutki tarkkaan Husserlin teoksia ja rakensi omaa fenomenologiatulkintaansa niistä käsin. Hän perehtyi Husserlin varhaisten julkaisujen lisäksi myös suureen joukkoon julkaisemattomia käsikirjoituksia. Näissä Husserl eteni tutkimaan kokemuksen niitä muotoja, jotka vielä varhaisteoksissa olivat toissijaisia. Husserl kuvasi ja jäsensi tiedollisten asenteiden lisäksi myös käytännöllisiä, esteettisiä ja moraalisia kokemuksia ja kehitti samalla uusia käsitteitä näiden kokemusmuotojen ymmärtämiseksi.

Merleau-Ponty esittää, että näissä myöhemmissä tutkimuksissaan Husserl onnistuu myös muotoilemaan uudelleen näkemyksensä maailmasta olevan kokonaisuutena horisontin ja tyylin käsitteiden avulla. Phénoménologie de la perception -teoksessa hän kirjoittaa Husserlia mukaillen:

Luonnollinen maailma on kaikkien horisonttien horisontti, kaikkien mahdollisten tyylien tyyli, ja se varmistaa kokemukseni ykseyden, joka säilyy huolimatta henkilöllisen ja historiallisen elämäni keskeytyksistä 
ja jota en suinkaan valitse. Sen [luonnollisen havaintomaailman] vastine minussa on aistielinteni annetut ja yleiset toiminnot, jotka edeltävät henkilöllistä olemassaoloani ja määrittelevät ruumiin. ${ }^{16}$

Merleau-Ponty päätyy tästä lähtökohdasta käsin muotoilemaan uudelleen maailmavarmuuden käsitteen.

Uudelleenmuotoiluun vaikuttaa merkittävästi myös Merleau-Pontyn näkemys siitä, millaista on uskonnollinen kokemus ja usko Jumalaan. ${ }^{17}$ Hän esittää, ettei usko ole Jumalan olemassaoloa koskeva kannanotto eikä minkäänlainen tahdon akti, jossa jotakin asetettaisiin olemaan. Usko ei ole luonteeltaan kognitiivista vaan affektiivista - vastaamista siihen, miten Jumala meitä puhuttelee. Usko ei toisin sanoen ensi sijassa merkitse sitä, että vakuuttuisimme Jumalan olemassaolosta, vaan sitä, että vastaamme hänen kutsuunsa ja jättäydymme hänen hyvyytensä varaan. ${ }^{18}$

Tällaisena Jumalusko ylittää kaikki tiedon kohteet, ei siinä mielessä, että se sitoutuisi johonkin kattavampaan kuin tavanomaiset uskomukset ja toimisi jonkinlaisena super-uskomuksena. Päinvastoin Merleau-Ponty painottaa, että uskon sitoutuneisuus on sitoutuneisuutta johonkin, mikä kokonaan poikkeaa uskomisen ja tietämisen järjestyksestä eikä lainkaan jäsenny oliona tai asiantilana.

Merleau-Ponty soveltaa näkemystään Jumanuskosta kuvauksessaan maailmavarmuuden luonteesta. Phénoménologie de la perception -teoksessa hän kirjoittaa:

Kaikkien [...] aktien taustalla, niitä kannattamassa, on syvempi toiminto, jota ilman havaintomaailmalta puuttuisi todellisuus, niin kuin on skitsofreenikon tapauksessa [...] Tämä [syvempi funktio] on voima, joka eräänlaisen "uskon" tai "ensisijaisen näkemyksen” kautta vie meidät subjektiviteetin yli ja antaa meille paikan siinä maailmassa, joka edeltää tiedettä ja todentamista. ${ }^{19}$

Toisaalla Merleau-Ponty selvittää uskonnollisen kokemuksen luonnetta ja esittää, että uskon elementti on mukana jokaisessa havainnossamme:

Heti kun jätämme puhtaat geometriset ideat ja toimimme suhteessa reaalimaailmaan, on kyse uskosta - ehdottoman sitoumuksen mielessä, sellaisen joka ei koskaan ole täysin oikeutettua. Jokainen havaintomme on uskon teko sikäli, että jokaisessa sitoudumme johonkin mitä emme tunne. ${ }^{20}$

Maailmavarmuudessa ei siis Merleau-Pontyn mukaan ole kyse minkäänlaisesta predikaatiosta eikä propositionaalisesta asenteesta, jossa oliolle omistettaisiin jokin piirre. ${ }^{21}$ Maailmavarmuus ei jäsenny väitelauseiksi muotoa "Maailma on todellinen" tai "On olemassa maailma". Se joka epäilee maailman todellisuutta, Merleau-Ponty selittää, ei itse asiassa tiedä mitä kysyy, sillä maailma ei ole minkäänlainen olio eikä olioiden kokonaisuus vaan "ehtymätön varanto, josta kaikki oliot nousevat esille". ${ }^{22}$

Voimme toki suorittaa filosofisia harjoituksia ja pidättäytyä uskomasta olioiden olemassaoloon. Ja juuri näinhän Descartes Mietiskelyissään eteni kyseenalaistaessaan kaikki omaksumansa uskomukset ja etsiessään varmaa epäilyksetöntä perustaa tiedolle.

Descartes hylkäsi ensin aistimuksiin ja aistihavaintoon perustuvat uskomuksensa huomauttamalla, että aistit pettävät meidät toistuvasti eivätkä siksi ole luotettavia tiedon lähteitä. Toisaalta hän tunnusti, että aistitieto osoittautuu virheelliseksi ainoastaan toisten aistihavaintojen ansiosta. Tämän vuoksi hän eteni tunnettuun uniargumenttiinsa ja kysyi: Entä jos kaikkien aistimusteni ja aistihavaintojeni moniaineksinen jatkumo olisi pelkkää unta? Miten pystyn erottamaan havaintotilan unitilasta, kun molemmat etenevät omalla johdonmukaisuudellaan? Descartes vastasi päättelemällä:

Kuinka usein öinen lepo vakuuttaakaan minut sellaisista tavanomaisista asioista että olen tässä, kaapuun pukeutuneena, tulen ääressä istumassa - , kun kuitenkin 
makaan riisuuntuneena lakanoiden välissä! Ja kuitenkin nyt tajuan valppain silmin tämän paperin, liikutan päätäni eikä se ole unessa, ojennan [paperin] tahallani ja tietoisesti ja aistin sen. Nukkuvalla tämä ei voisi olla niin tarkkaa. Ikään kuin en muistaisi, että samanlaiset ajatukset ovat usein myös johtaneet minut harhaan unissa! Kun ajattelen tätä huolellisemmin, näen selvästi, ettei valvetilaa voi erottaa unesta millään varmoilla tuntomerkeillä - niin selvästi, että hämmennyn, ja tämä hämmennyskin melkeinpä vahvistaa käsitystä, että olen unessa. ${ }^{23}$

Descartesin uniargumentti jätti kuitenkin koskemattomaksi geometriset ja matemaattiset totuudet, Descartes sanoin: "Sillä valveilla ja unessa kaksi ja kolme ovat yhteensä viisi, eikä neliöllä ole ole enempää kuin neljä sivua."24

Horjuttaakseen sitoutumistamme myös näihin totuuksiin Descartes kuvasi pahansuovan kaikkivaltiaan, jumalan tai pahan hengen, joka oli laatinut maailman ja meidät sen osana sellaisella tavalla, että systemaattisesti erehdymme kaikkein ilmeisimmissäkin väitteissämme, esimerkiksi matemaattisissa yhtälöissä. Descartes pyrki metodisen epäilynsä avulla irrottautumaan siis aistikohteista, omasta ruumiistaan, tila-ajasta ja matemaattisista totuuksista ja päätyi näin ainoaan täysin epäilyksettömään olemistyyppin: omaan olemassaoloonsa ajattelevana subjektina. ${ }^{25}$

Merleau-Ponty ei torju Descartesin epäilyn metodia vaan päinvastoin näkee siinä (Husserlin tavoin) mahdollisuuden filosofisen vastuun uudistamiseen. ${ }^{26}$ Tämä mahdollisuus voi Merleau-Pontyn mukaan toteutua ainoastaan, jos tutkimme ennakkoluulottomasti sitä kokemuksellista perustaa, jonka varassa Descartesin ajatus ja keskustelu etenee. Näin Merleau-Ponty päätyy argumentoimaan, että kartesiolainen epäily - yhtä lailla kuin totunnainen uskomus ulkomaailman olemassaolosta - toimii perustavamman sidoksen varassa: käytännöllisen ja viime kädessä affektiivisen. Descartes muotoilee metodiset kysymyk- sensä luottaen maailman kestoon ja kantavuuteen ja kirjaa ne paperille varmana siitä, että pystyy aina tahtoessaan ottamalla muistiinpanonsa esille ja jakamaan kirjoituksensa toisille siinä toivossa, että saisi kuulla heidän mahdolliset kriittiset huomautuksensa.

Koko radikaalin epäilyn ja vapaan kyseenalaistamisen hanke, sen mieli, lepää Merleau-Pontyn mukaan syvemmän toiminnallisen luottamuksen varassa. Mikään uskomus tai kannanotto maailma olemassaoloon ei pysty vahvistamaan tätä luottamusta eikä minkäänlainen metodinen epäily onnistuu sitä horjuttamaan. ${ }^{27}$ Maailmavarmuuden järkkyminen ei ole älyllinen tapahtuma vaan emotionaalinen prosessi, ja äly - onneksemme - voi tulla avuksi silloin, kun tämä perustavampi luottamus alkaa horjua.

Mutta mikä on tällaisen luottamuksen aiheena? Millainen kokonaisuus on se maailma, jonka kestävyys antaa mahdollisuuden tutkia ja kyseenalaistaa yksittäisiä olioita ja asiantiloja, ja viime kädessä myös asettaa teoreettisen kysymyksen oliokokonaisuuden olemassaolosta?

Merleau-Ponty vastaa tähän kuvaamalla havaintomaailman affektiivisten aistipiirteiden ainutkertaiseksi kudelmaksi, johon havaitsija on kietoutunut aistivana ruumiina. Selvitän artikkelini lopuksi lyhyesti tämän vastauksen perustekijöitä: käsitystä maailmasta affektivisena ja $k u$ doksellisena rakenteena.

Ensinnäkin Merleau-Ponty hylkää sen modernia filosofiaa pitkälti hallinneen ajatuksen, että havainnon paljastama todellisuus on vapaa affektiivisista arvoista. ${ }^{28}$ Hän argumentoi, että kaikki havaintomaailman asiat, kaikki piirteet ja muodot, koskettavat ja liikuttavat meitä. Me näemme esimerkiksi värejä, jotka vangitsevat katseemme ja saavat meidät taipumaan puoleensa. Kuulemme epämiellyttäviä ääniä, jotka saavat meidät kääntymään pois tai siirtymään kauemmas. Merleau-Ponty kuvaa havaintomaailman hajujen, äänien, makujen, värien, valöörien, hahmojen ja 
muotojen täyttämäksi voimakentäksi, jossa aistiva rumiimme liikkuu ja suuntautuu. ${ }^{29}$

En siis havaitse esimerkiksi pöydän pintaa molekyyleista koostuvana rakenteena, mutta en myöskään näe sitä ainoastaan käytännöllisenä objektina, vaikkapa alustana joka kannattelee käsiteltäviä esineitä. Näen pinnan ensi sijassa jonakin, mikä houkuttelee kättäni tiettyyn liikkeeseen, ikään kuin "ohjaa ja kuljettaa kättä itseään pitkin”. ${ }^{30}$

Merleau-Ponty puhuu tässä yhteydessä siitä, miten maailma ja erilaiset luonnonoliot "kutsuvat" ja "puhuttelevat" meitä. ${ }^{31}$ Tarkoituksena ei ole postuloida erillisiä luonnonhenkiä vaan antaa teoreettisista ja käytännöllisistä ennakkositoumuksista vapaa kuvaus kokemuksen perustavista kerroksista:

Näkyvä asia (kuun kalpea kiekko) tai kosketettava asia (kalloni sellaisena kuin sen tunnen koskettaessani sitä), joka pysyy samana [kokonaisen] elämyssarjan läpi, ei ole sen enempää todella pysyvä kvaliteetti kuin käsite tai tietoisuus tällaisesta objektiivisesta ominaisuudesta vaan se, minkä katseemme tai ruumiinliikkemme löytää tai omaksuu, kysymys johon nämä [liikeet] vastaavat täsmällisesti. Katseelle tai kosketukselle tarjoutuva kohde herättää tietyn liike-intention, joka ei kohdistu oman ruumiimme liikkeisiin vaan asiaan itseensä, josta ne ovat ikään kuin riippuvaisia. Ja sikäli kuin käteni tuntee kovuuden tai pehmeyden, sikäli kuin katseeni tuntee kuun valon, kyse on tietystä tavasta kytkeytyä ilmiöön ja kommunikoida sen kanssa. ${ }^{32}$

Affektivisuus - vetovoima ja loitontava voima - ei Merleau-Pontyn mukaan ole lisäpiirre, jonka kokeva subjekti ikään kuin jälkikäteen liittää havaintokokemuksen antamaan perustavaan olemiskerrokseen. ${ }^{33}$ Päinvastoin arvovapaat teoreettiset kohteet abstrahoidaan ensisijaisista affektiivisista kohteista. Vastaavasti ajatus sellaisesta havainnosta, joka toisi eteemme puhtaan olevan vailla affektiivisuutta, on abstraktio havainnosta sellaisina kuin sen elämme.
Filosofinen virhearvio, jonka mukaan affektiivinen on vain "projisoitu lisä", johtuu siitä, että rajaamme kokemusta koskevat tutkimuksemme valmiiksi rakentuneisiin kohteisiin - käytännöllisiin objekteihin ja luonnontieteiden objekteihin - emmekä selvitä sitä elämyksellistä pohjaa, josta käsin nämä kohteet rakentuvat. Tämä laiminlyönti merkitsee, ettemme käsitä, miten objektiivinen oleminen ja käytännöllinen "jotakin varten" oleminen muodostuvat vaan joudumme edellyttämään niiden itseriittoisuuden - tai lykkäämme niiden tutkimusta hamaan tulevaisuuteen.

Yksilöhistoriallisesti ymmärrettynä väite havainnon affektiivisuudesta ei tietenkään ole hämmästyttävä vaan päinvastoin osa arkipsykologista ymmärrystämme. Merleau-Ponty ei kuitenkaan esitä väitettään psykologisena, puhe on kokemusrakenteiden ensisijaisuudesta: kaikki kokemus ja kaikki kokemuksen kohteet, viime kädessä myös teoreettisen tiedon objektit, rakentuvat hänen mukaansa havainnon perustalta - tässä Merleau-Ponty on yhtä mieltä Husserlin kanssa. Mutta "Husserlista" - ainakin kognitivistiksi tulkitusta Husserlista - poiketen Merleau-Ponty argumentoi, että havainto on olennaisesti, siis välttämättä, perustaltaan affektiivista. Voimme toki aina abstrahoida elämyksestämme pois affektiiviset tekijät, mutta pelkkä materiaalinen kappale ilman mitään, mikä liikuttaisi havaitsijaa, on ajatuksen konstruktio. Se ei ole mitään, minkä kukaan (edes enkelit tai Jumala) voisi havaita, nähdä, tuntea, kuulla tai maistaa. ${ }^{34}$

Havaintokohteiden affektiiviset piirteet muodostavat Merleau-Pontyn termein maailman lihallisen kudoksen. Esimerkiksi tämä valkoinen, jonka näen edessäni, on sisäisissä suhteissa muihin aistikvaliteetteihin. Se ei olisi, mitä on, ilman sileää pintaansa, joka heijastaa valon liikkeitä tyypillisellä tavallaan. Toisaalta tämä valkoinen kytkeytyy myös valkoisten verkostoon. Se ei olisi, mitä on, ellei eroaisi toisista valkoisista niiden erilaisissa merkitysyhteyksissä: valkoisesta lumessa, kielon 
lehdessä, antautumisen lipussa ja pyhien miesten kaavuissa. Merleau-Ponty kirjoittaa:

Tämä [valkoinen] on, mitä on, ainoastaan kytkeytymällä toisiin [valkoisiin], jotka ympäröivät sitä ja joiden kanssa se muodostaa kuvion, ja kytkeytymällä toisiin väreihin, joita hallitsee tai jotka hallitsevat sitä, joita se vetää puoleensa tai jotka vetävät sitä puoleensa, jotka se torjuu tai jotka torjuvat sen. Lyhyesti sanottuna, tämä [valkoinen] on tietty säie tai silmukka samanaikaisten ja toisiaan seuraavien [valkoisten] kudoksessa. Se ei ole atomi vaan näkyvyyden tiivistymä [concretisation]. ${ }^{35}$

Merleau-Ponty siis ehdottaa, että ajattelisimme maailman kudokseksi, johon itse sitoudumme aistivan ruumiimme kautta, sen sijaan että ajattelisimme sen edessämme seisovaksi olioksi tai oliokentäksi, joka yhtä lailla avautuu edessämme.

Luottamus tällaiseen maailmaan on luottamusta kudoksen kestävyyteen sanan kah- dessa merkityksessä. Yhtäältä me sitoudumme asioiden moninaisiin suhteisiin. Toisaalta maailman kudos on dynaminen rakenne, joka kestää yksittäiset kyseenalaistukset ja murtumat, mutta voi myös horjua - ja horjuu silloin kun sidosten affektiiviset voimat heikkenevät, sairaudessa ja kuolemassa. ${ }^{36}$

Luottamus maailmaan muistuttaa Jumaluskoa sikäli, että se on suhde tuntemattomaan. Yhteistä on myös se, että uskon kohde on molemmissa tapauksissa absoluuttinen eli kehys, jonka puitteissa kaikki suhteellinen on mahdollista.

Lopuksi maailmavarmus on Jumaluskon kaltaista myös sikäli, ettei maailma sen kohteena ole yleinen seikka eikä käsite vaan ainutkertainen yksilö - Merleau-Pontyn sanoin: se on kaikkea "objektivaatiota edeltävä yksilö, jonka hallitseva [ikään kuin majesteettinen] ykseys antaa tiedolle sen kohteen". ${ }^{37}$

\section{vi i t t e e t}

1. Artikkeli pohjautuu esitelmään "Filosofia ja luonnollinen asenne: epäily, uskominen ja tietäminen”, jonka pidin 25. huhtikuuta 2007 Helsingin yliopiston Tutkijakollegiumin järjestämässä Studia Collegialia -sarjassa Ihminen ja yhteiskunta tutkimuksen valossa. Olen Joona Taipaleelle ja Jussi Backmanille suuresti kiitollinen korjausehdotuksista, jotka auttoivat muokkaamaan esitelmätekstin julkaisuksi.

2. Fuchs 2004, 9. Thomas Fuchs on pitänyt lukuisia esitelmiä, joissa hän on jäsentänyt masennuskokemuksen tilallisuutta ja ajallisuutta fenomenologisin menetelmin ja käsittein, mm. "Melancholia as a desynchronization: Towards a psychopathology of interpersonal time" ja "The phenomenology of body and space in depression". Traumakokemuksen fenomenologiaa ovat tehneet mm. Rudolf Bernet ja Elisbeth A. Behnke.

3. Fuchs 2004, 11. Fenomenologisista skitsofreniatutkimuksista ks. mm. Sass 2001, Sass ja Parnas 2001, Urfer 2001, Sass ja Parnas 2003.

4. Fuchs 2004, 11.
5. Fuchs 2004, 11.

6. Fenomenologinen selvitys maailmavarmuudesta muistuttaa mielenkiintoisesti Wittgensteinin analyysia uskomuksen, tiedon ja varmuuden eroista (esim. [1969] 1975, \$308, 82, \$520, 118, \$550, 123). Varmuudesta-teoksessa Wittgenstein kirjoittaa esimerkiksi seuraavasti: "Mutta maailmakuvaani minulla ei ole siksi, että olen vakuuttunut sen paikkansapitävyydestä. Eikä siksi, että olen tällä hetkellä vakuuttunut sen paikkansapitävyydestä. Se on peritty tausta, jolla teen eron toden ja epätoden välillä" ([1969] 1975, \$94, 51, vrt. myös \$511, 116).

7. Merleau-Pontyn ja Husserlin filosofioiden suhteesta, ks. Heinämaa 2000, 2002.

8. Fenomenologian ja psykologian - sekä empiirisen että eideettisen - suhteista ks. Heinämaa 2004, 176-178.

9. Husserl Hua18, vrt. Hua1.

10. Vrt. von Wright [1972] 1975, 25-26.

11. Husserl Hua3, 48-53, 88-90, 216-217, vrt. Hua4, 162-163, 208-209, 299.

12. Husserl Hua3, 69-75.

13. Husserl Hua4, 25-26, 181-190, vrt. Witt- 
genstein [1969] 1972, \$600-612, 131-134, ks. myös von Wright [1972] 1975, 19-20.

14. Husserl Hua3, 238-240, Hua4, 16-18. Tässä on kuitenkin tärkeä huomata kaksi seikka. Ensinnäkin Husserlin varhaiset muotoilut eivät ole yksiselitteisiä vaan jättävät auki mahdollisuuden kahteen eri tulkintaa. Olen tässä seurannut tulkintaperinnettä, jonka mukaan aistimellinen kohde on Husserlin mukaan itsenäinen ja riippumaton kokonaisuus. Tämä ei suinkaan ole kiistatonta: toisen tulkinnan mukaan Husserl esittää ainoastaan, että aistikohde voidaan kyllä erottaa arvopiirteistä abstraktiolla mutta kohde esiintyy kokemuksessa alunperin juuri affektiivisten piirteiden sävyttämänä.

Toiseksi Husserlin myöhemmät muotoilut tekevät selväksi, että arvovapaat aistikohteet ovat abstrahoivan ajattelun tuotteita eivätkä aistikokemuksen yksiköitä. Niin sanotuissa Intersubjektivisuus-niteissä Husserl kirjoittaa muun muassa seuraavasti: "Kaikki, mitä on, koskettaa tunteitamme; jokainen oleva havaitaan arvohavainnossa ja niinpä jokainen herättää haluavia asenteita [begehrende Stellungsnahmen]" (Hua15 404-405); ja eräässä käsikirjoituksessa vieläkin eksplisiittisemmin: "Pelkkä aistimellinen aines ja korkeamman tason [puhtaat] aistikohteet - subjektille läsnäolevina olioina ilman arvoa - ovat abtsraktioita. Ei ole mitään, mikä ei koskettaisi tunteitamme" (Husserl Ms A VI 26, 42a, lainattu teoksesta Drummond 2006).

Varhaisten ja myöhäisten muotoilujen ero mahdollistaa kaksi käsitystä Husserlin ajattelun kehityksestä: Ensinnäkin on mahdollista, että Husserl näki arvovapaat aistikohteet aina abstraktion tuloksina, jolloin varhainen teesi doksisten aktien ensisijaisuudesta koskisi ainoastaan eletyn kokemuksen mahdollisia muunnelmia. Toinen mahdollisuus on, että Husserl muutti käsitystään arvovapaiden aistikohteiden asemasta kokemuksessa.

15. Auki jää kysymys, voiko kokija lainkaan elää, jos kokemus menettää kaiken affektiivisuutensa, sekä ympäristön affektiivisuuden että kaiken itse-affektion.

16. Merleau-Ponty [1945] 1993, 330.

17. Tuore teos uskonnollisen kokemuksen fenomenologiasta on Anthony Steinbockin Phenomenology and Mysticism: The Verticality of Religious Experience (2007).
18. Zettel-teoksessaan Wittgenstein kirjoittaa: "Et voi kuulla, kun Jumala puhuu toisen henkilön kanssa; voit kuulla hänet ainoastaan silloin, kun hän puhuttelee sinua" (\$717, vrt. Wittgenstein [1953] 1981, \$373, 188, [1977] (1984) 64, 85-86). Wittgensteinin ja Merleau-Pontyn uskokäsitysten yhteisenä perustana on Kiekegaardin uskonnonfilosofia. Wittgensteinin ja Kierkegaardin yhteyksistä tarkemmin ks. Greegan 1989.

19. Merleau-Ponty [1945] 1993, 343.

20. Merleau-Ponty [1966] 1996, 217.

21. Vrt. von Wright [1970] 1972, 26.

22. Merleau-Ponty [1945] 1993, 344, vrt. Wittgenstein [1969] 1972, \$20, 38, \$36, 41.

23. Descartes [1641] 2002, 33.

24. Descartes [1641] 2002, 34.

25. Descartes [1641] 2002, 38.

26. Merleau-Pontyn ja Husserlin Descartes-suhteista ks. Heinämaa 2000, 23-36 ja Heinämaa 2003.

27. Vrt. Wittgenstein [1969] 1972, \$675-676, 144.

28. Merleau-Ponty seuraa tässä Sartrea, joka jo L'imaginaire-teoksessa (1940) argumentoi, että havaintokohteen läsnäolo on riippuvainen aistimellisten piirteiden kokonaisuudesta. L'être et le néant-teoksessa Sartre esitti tämän idean käyttäen esimerkkinään sitruunan havaintoa: "Sitruunan keltainen ei ole subjektiivinen tapamme tajuta sitruuna; keltainen on sitruuna. Objekti X ei ilmene tyhjänä muotona, joka kokoaa yhteen erilliset kvaliteetit. Itse asiassa sitruuna ulottuu kaikkiin kvaliteetteihinsa, ja jokainen sen kvaliteeteista ulottuu kaikkiin muihin. Sitruunan happamuus on keltaista; ja keltaisuus on hapanta" (Sartre [1943] 1998, 649, vrt. 222). Merleau-Ponty kuljettaa koko Phénoménologie de la perception -teoksen läpi esimerkkiä sinisen villamaton havaitsemisesta. Argumentti tiivistyy luvussa "La chose et le monde naturel", jossa MerleauPonty kirjoittaa muun muassa seuraavasti: “'Todellinen' [le 'réel'] on ympäristö, jossa jokainen osa on erottamaton toisista ja lisäksi samamerkityksinen muiden kanssa, jossa kaikki 'aspektit' viittaavat toisiinsa täysin samanarvoisina. Se on ylittämätöntä runsautta: on mahdotonta kuvata maton väriä sanomatta, että kyseessä on villamatto, viittaamatta tiettyyn tuntoarvoon, tiettyyn painoon ja tiettyyn kykyyn eristää ääntä" ([1945] 1993, 373). 
29. Vrt. viite 14 .

30. Merleau-Ponty [1945] 1993, 367, vrt. 364.

31. Merleau-Ponty [1945] 1993, 123, 161, 1964 183.

32. Merleau-Ponty [1945] 1993, 366-367.

33. Merleau-Ponty [1945] 1993, 31-32, 369-371.

34. Merleau-Ponty [1945] 1993, 249-250.
35. Merleau-Ponty 1964, 174. Merleau-Pontyn esimerkkinä on punainen väri ja eri punaisten väliset kytkökset; olen vaihtanut värin esitelmätilanteeseen paremmin sopivaksi valkoiseksi.

36. Vrt. von Wright [1970] 1975, 20-21.

37. Merleau-Ponty [1945] 1993, xiii.

\section{K I R J A L LI S U US}

Descartes, René [1641] (2002) Mietiskelyjä ensimmäisestä filosofiasta. Suom. Tuomo Aho. Teoksessa Teokset II. Helsinki: Gaudeamus.

Drummond, John (2006) "Respect as a moral emotion", Husserl Studies vuosikerta 22, numero $1,1-27$.

Fuchs, Thomas (2004) "Disembodied minds: Pathologies of body awareness and body action", esitelmä Embodied Mind kokouksessa. Kööpenhaminan yliopisto, kesäkuu 14-16 2004.

Greegan, Charles L. (1989) Wittgenstein and Kierkegaard: Religion, Individuality and Philosophical Method. London: Routledge. Verkkojulkaisu http://home.clear.net.nz/ pages/ccreegan/wk/ 1997.

Heinämaa, Sara (2000) Ihmetys ja rakkaus: esseitä ruumiin ja sukupuolen fenomenologiasta. Helsinki: Nemo.

Heinämaa, Sara (2002) "From decisions to passions: Merleau-Ponty's interpretation of Husserl's reduction", teoksessa Ted Toadvine ja Lester Embree (toim.) MerleauPonty's Reading of Husserl. Dordrecht, Boston, Lontoo: Kluwer, 127-146.

Heinämaa, Sara (2003) "The living body and its position in metaphysics: Merleau-Ponty's dialogue with Descartes", teoksessa Dan Zahavi, Sara Heinämaa ja Hans Ruin (toim.) Metaphysics, Facticity, Interpretation: Phenomenology in the Nordic Countries. Haag: Kluwer, 23-48.

Heinämaa, Sara (2004) "Sielusta, ruumiista ja hengen elämästä: Husserlin (ennakko)vastaus Heideggerin huomautuksiin", Ajatus, 167-208.

Husserl, Edmund (Hua1) Cartesianische Meditationen und pariser Vorträge. Toim. Stephan Strasser. Haag: Martinus Nijhoff, 1950.
Husserl, Edmund (Hua3) Ideen zu einer reinen Phänomenologie und phänomenologischen Philosophie, Erstes Buch: Allgemeine Einführung in die reine Phänomenologie. Toim. Walter Biemel. Haag: Martinus Nijhoff, [1913] 1950.

Husserl, Edmund (Hua4) Ideen zu einer reinen Phänomenologie und phänomenologischen Philosophie, Zweites Buch: Phänomenologische Untersuchungen zur Konstitution. Toim. Marly Bimel. Haag: Martinus Nijhoff, 1952.

Husserl, Edmund (Hua15) Zur Phänomenologie der Intersubjektivität, Texte aus dem Nachlass, Dritter Teil 1929-35. Toim. Iso Kern. Haag: Martinus Nijhoff, 1973.

Husserl, Edmund (Hua15) Logische Untersuchungen, Erster Band: Prolegomena zur reinen Logik. Toim. Elmar Holenstein. Haag: Martinus Nijhoff Publishers, [1900] 1975.

Merleau-Ponty, Maurice [1945] (1993) Phénoménologie de la perception. Pariisi: Gallimard.

Merleau-Ponty, Maurice (1964) Le visible et l'invisible. Toim. Claude Lefort. Pariisi: Gallimard.

Merleau-Ponty, Maurice [1966] (1996) Sens et non-sens. Pariisi: Gallimard.

Sartre, Jean-Paul [1943] (1998) L'être et le néant: essai d'ontologie phénoménologique. Pariisi: Gallimard.

Sass, Louis A. (2001) "Self and world in schizophrenia: Three classical approaches", Philosophy, Psychiatry, \& Psychology, 8. vuosikerta, 4. numero, 251-270. Verkkojulkaisu http://muse.jhu.edu 2002.

Sass, Louis A. ja Josef Parnas (2001) "Phenomenology of self-disturbances in schizophrenia: Some findings and directions", Philosophy, Psychiatry, \& Psychology, 8. 
vuosikerta, 4. numero, 347-355. Verkkojulkaisu http://muse.jhu.edu 2002.

Sass, Louis A. ja Josef Parnas (2003) "Schizophrenia, consciousness, and the self", Schizophrenia Bulletin, 29. vuosikerta, 3. numero, 427-444.

Steinbock, Anthony (2007) Phenomenology and Mysticism: The Verticality of Religious Experience. Indiana University Press.

Urfer, Annick (2001) "Phenomenology and psychopathology of schizophrenia: The views of Eugene Minkowski", Philosophy, Psychiatry, \& Psychology, 8. vuosikerta, 4. numero, 347-355. Verkkojulkaisu http:// muse.jhu.edu 2002.

von Wright, Georg Henrik [1970] (1972) "Wittgenstein varmuudesta", teoksessa Ludwig Wittgenstein Varmuudesta. Suom. Heikki Nyman. Porvoo, Helsinki: Werner Söderström Osakeyhtiö.

Wittgenstein, Ludwig [1953] (1981) Filosofisia tutkimuksia. Suom. Heikki Nyman. Porvoo,
Helsinki, Juva: Werner Söderströn Osakeyhtiö.

Wittgenstein, Ludwig [1967] (1978) Zettel — filosofisia katkelmia. Suom. Heikki Nyman. Toim. ja julk. Georg Henrik von Wright ja G. E. M. Anscombe. Helsinki: Werner Söderström Osakeyhtiö.

Wittgenstein, Ludwig [1969] (1972) Varmuudesta. Suom. Heikki Nyman. Porvoo, Helsinki: Werner Söderström Osakeyhtiö.

Wittgenstein, Ludwig [1977] (1984) Culture and Value. Käänt. Peter Winch. Toim. ja julk. Georg Henrik von Wright yhdessä Heikki Nymanin kanssa. Chicago: The University of Chicago Press.

Wittgenstein, Ludwig (2001) Vorlesungen und Gespräche über Ästhetik, Psychoanalyse und religiösen Glauben. Käänt. Ralf Funke. Yorick Smythiesin, Rush Rheesin ja James Taylorin muistiinpanoista toim. ja julk. Cyril Barrett. Frankfurt am Main: Fisher Taschenbuch Verlag. 